
\title{
M.
}

\section{INFLUENCE INVESTMENT OPPORTUNITY SET, OPERATING PROFIT MARGIN, CASH FLOW FROM OPERATING ACTIVITIES AND CASH FLOW TO EQUITY ON POLICY DIVIDEND ON A METAL COMPANY THAT LISTED ON INDONESIA STOCK EXCHANGE}

\author{
Sri Fitri Wahyuni ${ }^{1}$, Fika Rimalansyah Peride ${ }^{2}$ \\ 1,2 Faculty Of Economics And Business, Universitas Muhammadiyah Sumatera Utara \\ Correspondence Address: J1. Mukhtar Basri no.3 Medan, Telp :061-6619056 \\ E-mail: ${ }^{1)}$ srifitri@umsu.ac.id
}

\begin{abstract}
The research objectives in this study are to find out and analyze the effect Investment Opportunity Set, To find out and analyze the effect Operating Profit Margin, To find out and analyze the effect of Cash flow from operating activities, to find out and analyze the effect Cash flow to Equity to the dividend payout ratio, to determine and analyze the effect of the Investment Opportunity Set, Operating Profit Margin, Cash Flow from Operating Activities and Cash Flow to Equity simultaneously on the Dividend Payout Ratio in metal companies listed on the Indonesia Stock Exchange for the 2016-2020 period. This study uses a quantitative approach, the regression analysis technique used in this study is a multiple linear regression analysis technique. The results of this study indicate that there is an influence between the Investment Opportunity Set on Dividend Policy. There is an effect of Operating Profit Margin on Dividend Policy. There is no influence of Cash Flow From Operating Activities on the Dividend Policy in. There is an effect of Cash Flow to Equity on Dividend Policy and the Fcount Value is 12, 130 with a significant level of 0.000, while Ftable is known to be 2.68. Based on these results, it can be seen that Fcount > Ftable $(12,130>2,68)$ so that $\mathrm{HO}$ is rejected and Ha is accepted so it can be concluded that the variables of Investment Opportunity Set, Operating Profit Margin, Cash Flow From Operating Activities, Cash Flow to Equity together have significant influence on the Dividend Policy of Metal Companies Listed on the Indonesia Stock Exchange for the 2016-2020 period.
\end{abstract}

Keywords: Investment Opportunity Set, Operating Profit Margin, Cash Flow from Operating Activities, Cash Flow to Equity, Dividend Policy

\section{INTRODUCTION}

This research was conducted on metal companies listed on the IDX. Metal companies are engaged in general trading, product representatives or agents, contractors, manufacturing and fabrication industries, processing of aluminum and other metal products, printing and real estate and are engaged in the manufacture of steel and iron. Based on the Company's Articles of Association, the company's scope of activities mainly covers the iron and steel industry. The main business activities of metal companies listed on the IDX are currently engaged in the iron-concrete industry which is marketed domestically with a focus on the target market of distributors, iron shops and end users.

For investors, they tend to expect higher dividend payments, while management tends to hold cash to pay debts or increase investment. Dividends are distributions of company income which are the rights of shareholders which can be in the form of cash, assets, or other forms(Wirawati, 2016).

Dividend policy is a policy to distribute profits to shareholders which will be distributed in the form of dividends and the amount of retained earnings for business development needs. The proportion paid to shareholders depends on the ability to generate profits and the dividend policy adopted by the company. The percentage of profit paid to shareholders in the form of dividends is 
Influence Investment Opportunity Set, Operating Profit Margin, Cash Flow From Operating Activities And Cash Flow To Equity On Policy Dividend On A Metal Company That Listed On Indonesia Stock Exchange

DOI: $10.54443 /$ morfai.v1i2.102

called the dividend payout ratio (DPR). The distribution of larger dividends tends to increase the stock price which means an increase in the value of the company. The greater the profit, the greater the percentage of dividends so that the stock price will increase. Companies that have the ability to pay dividends are assumed by the public as profitable companies.

Investment opportunity setis the value of investment opportunities and is an option to make investments in the future. This investment opportunity set is related to the company's growth opportunities in the future. The company's growth is like an opportunity to invest in the future. The payment of dividends, especially cash dividends, is highly dependent on the available cash position.

Free cash flow owned by the company shows the cash available to investors. Free cash flow as cash available after all projects that generate a positive net present value (NPV) are carried out. Dividend payments reduce the free cash flow available for managers to invest. Companies with high cash flow rates should pay high dividends as well. Free cash flow is what often triggers the emergence of differences in interests between shareholders and managers.

When free cash flow is available, managers are allegedly going to waste the free cash flow so that inefficiency occurs in the company or will invest in free cash flow with a small return.(Sunarto \& Budi, 2010). The need for funds for the company is a factor that needs to be considered in determining the policy on dividends to be taken. In this study, the free cash flow as a proxy is free cash flow from operating activities and cash flow from funding (equity).

\section{THEORETICAL BASIS}

\subsection{Dividend Payout Ratio}

The measurement of dividend policy as proxied by the dividend payout ratio is an integral part of the company's funding decisions. The dividend payout ratio (Dividend Payout Ratio) is a ratio that measures the proportion of net profit per one share of common stock which is paid in the form of dividends. An investor will maintain ownership of shares of a company. If they anticipate that the stock is able to provide a better return than the stock of other companies.

According to (Halim, 2014), "Dividends are the distribution of profits given by the company issuing the shares for the profits obtained by the company".

Here are the goals and benefits of dividends (Fahmi, 2014) as follows:

a. Maximizing prosperity for shareholders

As an investor, investing in the capital market is to get dividends and the high value of dividends paid can affect stock prices. The high value of dividends paid will make investors believe that the company has promising prospects in the future.

b. Shows company liquidity

With the distribution of dividends, it can be expected that the company's performance will look good in the eyes of investors.

c. Investors view dividend risk as lower than capital gain risk

Usually the company will provide a fixed dividend in each period so that the company can survive in economic turmoil and can provide returns to investors.

d. Meet the needs of shareholders as a fixed income for consumption needs.

With dividends, the growth and prospects of the company can be known by the shareholders.

e. As a communication tool between managers and shareholders.

Information about the entire internal company is sometimes not known by shareholders.

Dividend payout ratio is widely used in valuation as a way of estimating dividends for the future period. Dividend Payout Ratio (DPR) can be formulated as follows(Murhadi, 2013).

Dividend Payout Ratio $=\frac{\text { Divident Per Saher }}{\text { Earning Per Share }} \times 100 \%$ 


\subsection{Investment Opportunity Set}

According to (Hasnawati, 2015) states that: "The Investment Opportunity Set is the relationship between current and future expenditures with value or returns and prospects as a result of investment decisions to create company value."

Then (Norpratiwi, 2017) stated that: "The Investment Opportunity Set describes the breadth of investment opportunities or opportunities for a company, but it really depends on the company's choice of expenditure for future interests."

Thus the investment opportunity set is an investment opportunity or investment opportunity owned by the company and has an influence on the views of managers, owners, creditors, and investors on the profitability and growth prospects of the company. In addition, the investment opportunity set is unobservable, so it is necessary to choose a proxy that can be related to other variables in the company.

Whereas(Harmono, 2015)explained that the investment opportunity net is: "The most important policy of the two other policies in financial management, namely funding decisions and dividend policy. Capital investment is the main aspect of financial management policy because investment is a form of capital allocation whose realization must produce benefits or profits in the future.

Measurement of Investment Opportunity Set which is used as follows:

$$
\text { CAP/MVA }=\frac{\text { Tambahan Modal dalam Satu Tahun }}{\text { TotalAset }} \text { (Kallapur, 2016) }
$$

\subsection{Operating Profit Margin}

According to (Sawir, 2018)"Operating profit is called pure in the sense that this amount is actually obtained from a company's operating results by ignoring financial obligations in the form of interest and obligations to the government in the form of tax payments. The higher the operating profit margin, the better the operations of a company will be."

\subsection{Profit Margin Determinants}

According to (Riyanto, 2015)The size of the profit margin on each sales transaction is determined by 2 factors, namely net sales and operating profit. The size of the operating profit or net operating income depends on the income and the amount of operating expenses.

With a certain amount of operating expense, the profit margin can be increased by suppressing or reducing sales, or by suppressing or reducing operating expansion. Thus, there are 2 alternatives in an effort to increase profit margins, namely:

1. By increasing operating expenses up to a certain level, efforts are made to achieve the maximum additional sales, or in other words the additional sales must be greater than the additional operating expenses. Changes in the amount of sales can be caused by changes in the selling price per unit of a certain product. Thus it can be related that the notion of increasing the level of sales here can mean increasing revenue from sales by:

a. Increase the volume of sales units at a certain level of sales price, or

b. Increase the selling price per unit of product in the area of sales in a certain unit.

2. By reducing the income from sales to a certain level, efforts are made to have subtractionoperating expenses as much as possible, or in other words, reduce business costs relatively larger than the reduced income from sales. Although the number of sales during a certain period is reduced, but because it is accompanied by a decrease in operating expenses that is more comparable, the result is that the profit margin is getting bigger.

Measurement of Operating Profit Margin The formula used to find OPM is as follows: 
Influence Investment Opportunity Set, Operating Profit Margin, Cash Flow From Operating Activities And Cash Flow To Equity On Policy Dividend On A Metal Company That Listed On Indonesia Stock Exchange

DOI: $10.54443 /$ morfai.v1i2.102

Operating Profit Margin $=\frac{\text { operating profit }}{\text { Sales }} \times 100 \%$

(Harahap, 2013)

\subsection{Cash Flow From Operating Activities}

According to (Syakur, 2015) defines operating cash flow as follows: "The company's principal revenue-producing activities and other activities are not investing and financing activities."

\subsection{Factors Affecting the Amount of Cash Inventory Minimum}

Cash is one of the elements of working capital with the highest level of liquidity. The greater the amount of cash in the company means the higher the liquidity. This means that the company has a smaller risk of not being able to meet its financial obligations, but this does not mean that the company should try to maintain a very large cash supply, because the greater the cash means the more money that is unemployed so that it will reduce profits. On the other hand, if the company only pursues profit, the cash inventory can be turned over or in working condition. If the company carries out this action, it means placing the company in a liquid state if at any time there is a billing.

The factors that influence the size of a company's minimum cash inventory according to(Riyanto, 2015)that is:

1. Balance between cash inflows with cash outflows.

The existence of a good balance regarding the quantity and timing of cash inflows and cash outflows within a company means that cash disbursements both in terms of amount and timing will be met from cash receipts, so the company does not need to have a large cash inventory. The balance is partly due to the suitability of the terms of purchase with the way of sale. This means, that the payment of debt will be met with cash derived from the sale of its production.

2. Deviations from the expected cash flows.

To maintain the liquidity of the company, it is necessary to make an estimate of the cash flow in the company. If the cash flows always match the estimates, the company does not face liquidity problems. For this company, it is not necessary to maintain a large minimum stock of cash, if the company often experiences deviations from what is estimated. Adverse deviations in cash outflows, for example, are strikes,

The formula used to find the ratio of Cash flow from Operating Activities is:

Cash flow from Operating Activities $=$ LnCash flow from Operating Activities

(IAI, 2009)

\subsection{Cash Flow To Equity}

According to the Statement of Indonesian Financial Accounting Standards (IAI, 2009)financing activities are activities that result in changes in the amount and composition of the company's capital and loans. Cash flows arising from financing activities need to be disclosed separately because it is useful for predicting claims on future cash flows by suppliers of the company's capital.

Statement of Indonesian Financial Accounting Standards (IAI, 2009)Examples of cash flows from financing activities are:

1. Cash receipts from the issuance of shares or other capital instruments;

2. Cash payments to owners to withdraw or redeem shares of the entity;

3. Cash receipts from the issuance of bonds, loans, notes, mortgages, short-term and long-term loan funds;

4. Loan repayment,

5. Cash payments by the lessee; 


\section{ORFAI JOURNAL Actual and International Issue}

The measurement of Cash Flow To Equity is as follows

Cash Flow to Equity = Ln Cash Flow to Equity (IAI, 2009)

\section{CONCEPTUAL FRAMEWORK}

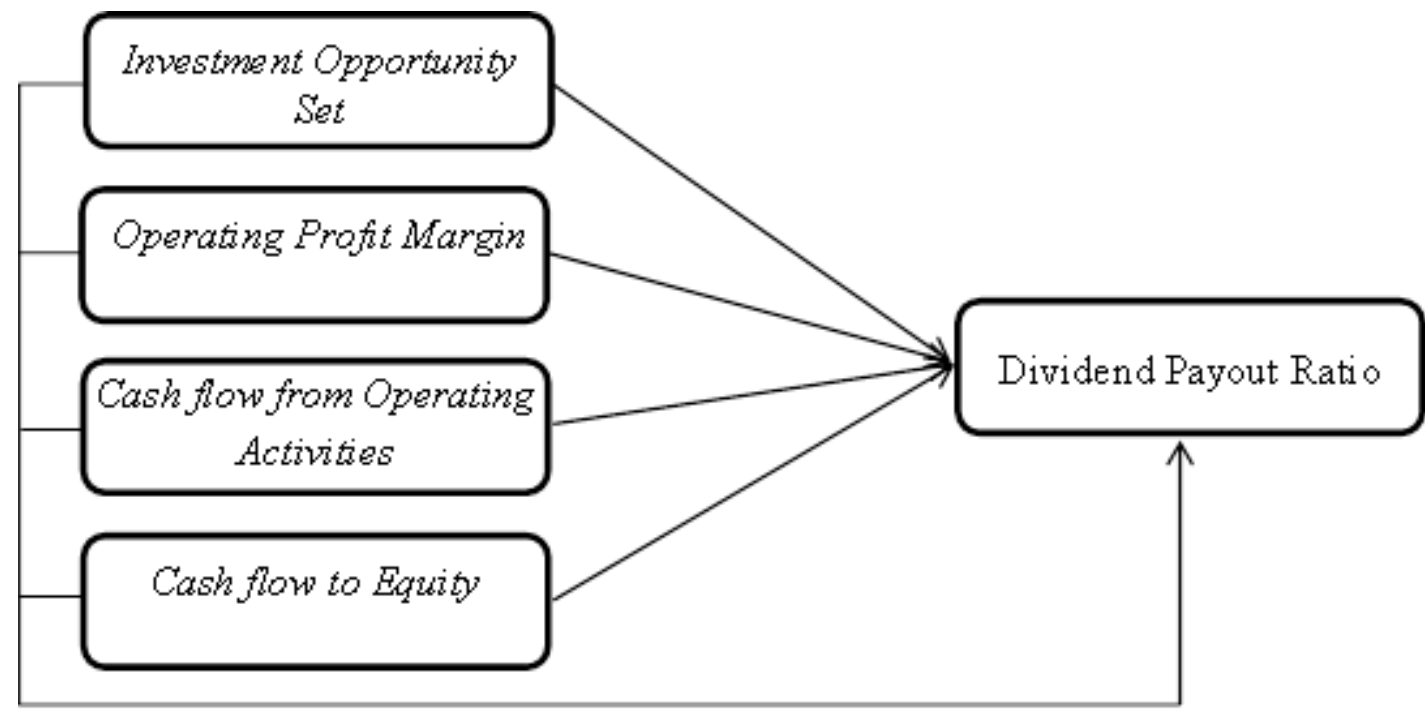

\section{HYPOTHESIS}

According to (Suryabrata, 2015)Hypotheses are temporary answers to research problems, the truth of which still has to be tested empirically. To provide a temporary answer to this research, the researcher needs to put forward a hypothesis, namely:

1. Investment Opportunity Set partially affect the Dividend Payout Ratio

2. Operating Profit Marginpartially affect the Dividend Payout Ratio

3. Cash Flow from Operating Activitiespartially affect the Dividend Payout Ratio

4. Cash Flow to Equitypartially affect the Dividend Payout Ratio

Investment Opportunity Set, Operating Profit Margin,Cash Flow from Operating

Activitiesand Cash Flow to Equity simultaneously have a joint effect on the Dividend Payout Ratio.

\section{IMPLEMENTATION METHOD}

The research approach that the author uses in this study is an associative approach, which is an approach to determine the relationship of one or more variables with other variables(Sugiyono, 2016). The data used in this study are the balance sheet and income statement and cash flow statements which aim to determine the factors that affect the dividend payout ratio, namely the Investment Opportunity Set, Operating Profit Margin, Cash Flow from Operating Activities and Cash Flow to Equity on registered metal companies. on the IDX for the 2016-2020 period.This research was conducted on metal companies listed on the Indonesia Stock Exchange period 2016-2021 on the site: www.idx.co.id

according to (Sugiyono, 2016)"Population is a generalization area consisting of objects/subjects that have certain qualities and characteristics determined by researchers to be studied and then drawn conclusions. The population used in this study are all metal and similar companies listed on the Indonesia Stock Exchange (IDX) during 2016 to 2020, namely 17 companies. according to(Juliandi, Irfan, \& Manurung, 2015)"The sample is representative of the population". This study used a purposive sampling technique. This technique is to select a sample from a population based 
Influence Investment Opportunity Set, Operating Profit Margin, Cash Flow From Operating Activities And Cash Flow To Equity On Policy Dividend On A Metal Company That Listed On Indonesia Stock Exchange

DOI: $10.54443 /$ morfai.v1i2.102

on certain considerations, both expert considerations and scientific considerations carried out in research. Based on this method, the samples in this study were 7 (ten) companies from 17 metal companies listed on the Indonesia Stock Exchange.Sources of data in this study are secondary data,where is secondary data. Secondary data is data taken not directly taken from the object of research but compiled or made based on existing primary data so that it becomes a report. The type of data is quantitative data, namely data that can be calculated or data in the form of numbers, in this study the data used are the financial statements of metal companies listed on the Indonesia Stock Exchange during 2016-2020.

Data collection techniques in this study were carried out using documentation techniques. This data analysis technique is the answer to the problem formulation that will be investigated whether each independent variable is Investment Opportunity Set, Operating Profit Margin,Cash Flow from Operating Activitiesand Cash Flow to Equityit affects the dependent variable t, namely dividend payout ratio beither partially or simultaneously. The data analysis method used in this research is multiple linear regression, classical assumption test consisting of normality test, multicollinearity test, heteroscedasticity test, and autocorrelation test, hypothesis test consisting of partial test ( $\mathrm{t}$ test) and simultaneous test (F test) and Determinant coefficient (R-Square).

\section{RESULTS AND DISCUSSION \\ RESEARCH RESULT}

\subsection{Normality test}

To see the dependent variable and independent variables that have a normal distribution or do not need normality testing. according to(Juliandi et al., 2015) "The data normality test is carried out to see whether in the regression model, the dependent and independent variables have a normal distribution or not". The normality test carried out in this study is

1) Kolmogrov smirnov . test

The Kolmogrov Smirnov test is a test that aims to determine whether or not the independent variable is normally distributed with the dependent variable or both.

Then the conditions for the Kolmogrov Smirnov test are as follows:

a) Asymp. Sig (2-tailed) $>0.05(\alpha=5 \%$, significant level) then the data is normally distributed.

b) Asymp. Sig (2-tailed) $<0.05(\alpha=5 \%$, significant level) then the data is not normally distributed. 


\section{Morfal journal Multidiciplinary Output Research For Actual and International Issue}

Table 1 Kolmogorov Smirnov. Test Results

One-Sample Kolmogorov-Smirnov Test

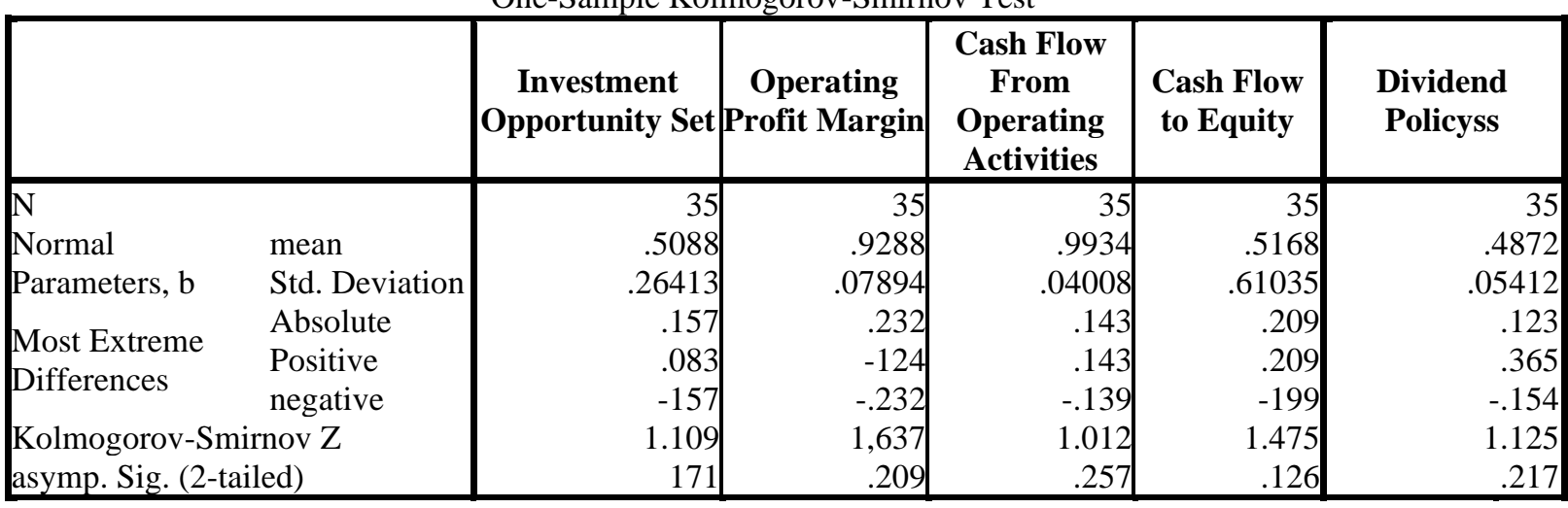

a. Test distribution is Normal.

b. Calculated from data.

Source: SPSS 20 research results

The value of each variable has met the standards that have been set, and can be seen in the Asym line. Sig. (2-tailed). From that line the Asym value. Sig. (2-tailed) $>0.05$. This shows a normally distributed variable.

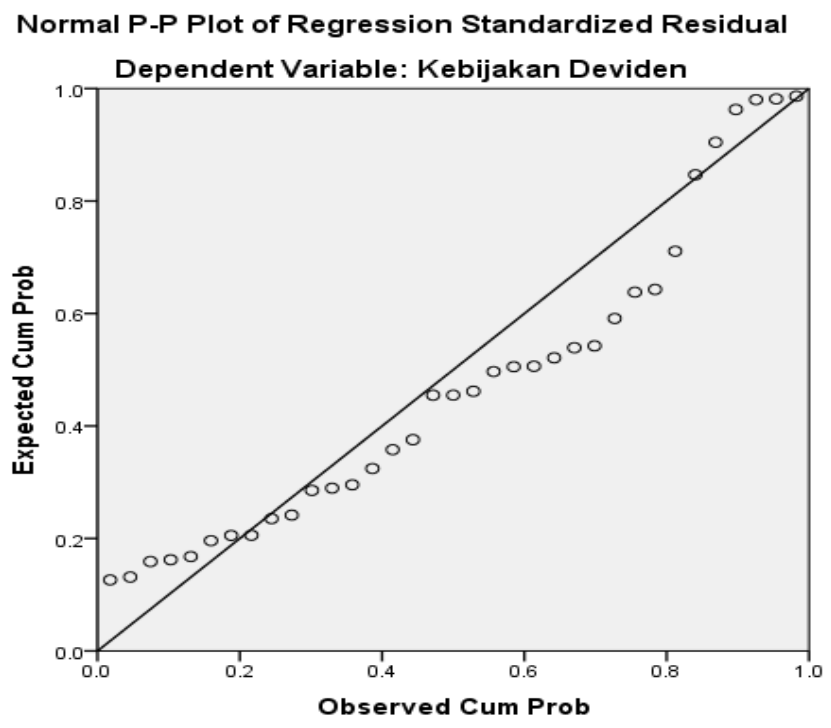

In Figure 4.1 the results of the effect of data normality show that on the normal plot graph, the dots spread out close to the diagonal line. So it can be concluded that the regression model is normally distributed, so it is feasible to use.

\subsection{Multicollinearity Test}

The multicollinearity test was used to test whether the linear regression model found a high correlation between the independent variables, with the following conditions:

1) If VIF $>5$ then there is a serious multicollinearity problem.

2) If $\mathrm{VIF}<5$ then there is no serious multicollinearity problem. 
Volume 1 No 2 (2021)

Influence Investment Opportunity Set, Operating Profit Margin, Cash Flow From Operating Activities And Cash Flow To Equity On Policy Dividend On A Metal Company That Listed On Indonesia Stock Exchange

DOI: $10.54443 /$ morfai.v1i2.102

Coefficientsa

Table 4.7 Multicollinearity Test Results

\begin{tabular}{|c|c|c|c|c|c|}
\hline \multirow{2}{*}{ Model } & \multicolumn{3}{|c|}{ Correlations } & \multicolumn{2}{|c|}{ Collinearity Statistics } \\
\hline & Zeroorder & Partial & Part & Tolerance & VIF \\
\hline (Constant) & & & & & \\
\hline IOS & .312 & .332 & .310 & .904 & 1.107 \\
\hline $1 \mathrm{OPM}$ & .341 & .271 & .248 & .740 & 1.351 \\
\hline Cash Flow Form Operating Activities & .196 & .001 & .001 & .804 & 1,244 \\
\hline Cash Flow to Equity & .196 & .103 & .091 & .717 & 1.395 \\
\hline
\end{tabular}

a. Dependent Variable: Dividend Policy

Source: SPSS 20 Research Results

Based on table 4.6 it can be seen that there is no multicollinearity problem because the VIF (Variable Inflation Fictory) is smaller than 5, namely the VIF Investment Opportunity Set of 1.107 which is smaller than 5. The value of and the value of the Operating Profit Margin is also smaller than 5 of 1.351. The value of and the value of Cash Flow From Operating Activities is also smaller than 5 by 1,244. and the value of Cash Flow to Equity is also smaller than 5 by 1.395 .

\subsection{Heteroscedasticity Test}

Test this aimto test whether in the regression model, there is an inequality of variance from the residuals of another observation. To find out whether or not there is heteroscedasticity in the regression model of this study, the analysis is carried out using informal methods. The informal method of heteroscedasticity testing is the Scatterplot graph method.

Decision making basis:

1) If certain patterns, such as existing dots form certain regular patterns (wavy, widen and then narrow), then heteroscedasticity occurs.

2) If there is no clear pattern, as well as points that spread above and below the number 0 on the $\mathrm{Y}$ axis, then there is no heteroscedasticity.

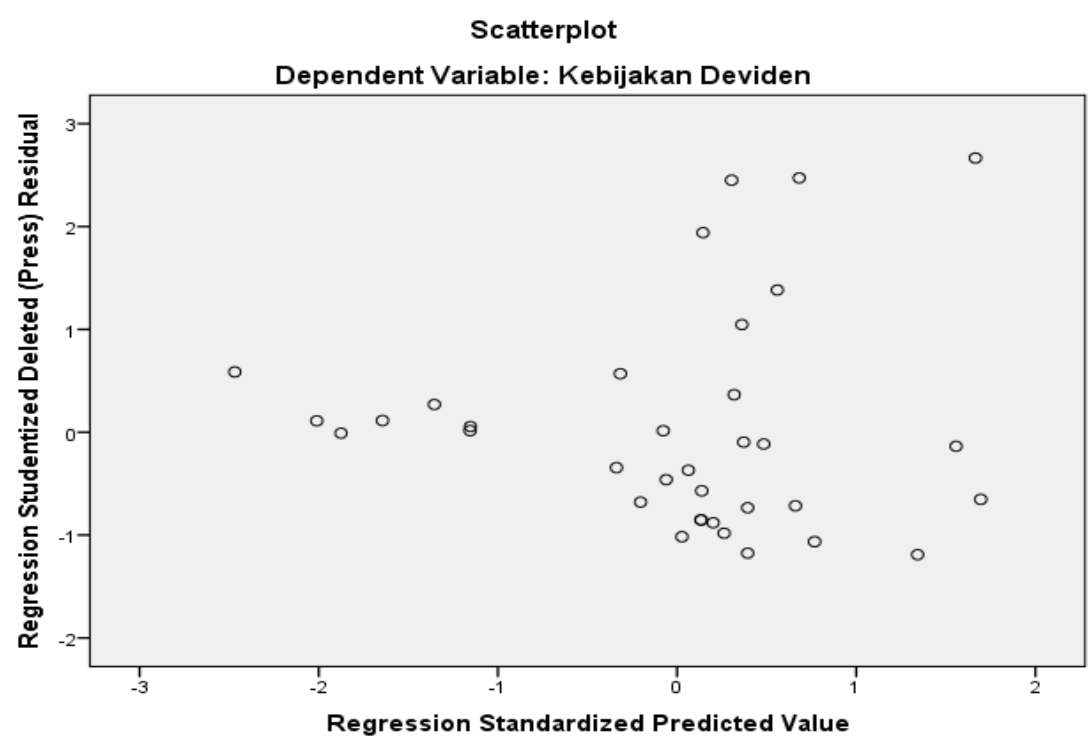

Figure 4.2 shows the circles forming an irregular pattern, where the points spread above and below the number 0 on the $\mathrm{Y}$ axis. Thus, there is no heteroscedasticity. 


\subsection{Autocorrelation Test}

The autocorrelation test aims to test whether in a linear regression model there is a correlation between the confounding error in period $t$ and the error in period $t-1$ (previous). If there is a correlation, it is called an autocorrelation problem. A good regression model is free from autocorrelation.

One way to identify it is to look at the Durbin Watson (DW) value:

1) If the DW value is below -2 , then there is a positive autocorrelation

2) If the DW value is between -2 to +2 then there is no autocorrelation

3 ) If the DW value is above +2 , then there is a negative autocorrelation.

Table 4.8 Autocorrelation Test Results

Model Summaryb

\begin{tabular}{|c|c|c|c|c|c|c|}
\hline \multirow[b]{2}{*}{ Model } & \multicolumn{5}{|c|}{ Change Statistics } & \multirow[b]{2}{*}{ Durbin Watson } \\
\hline & $\begin{array}{c}\text { R Square } \\
\text { Change }\end{array}$ & F Change & df1 & df2 & $\begin{array}{c}\text { Sig. F } \\
\text { Change }\end{array}$ & \\
\hline 1 & .221 & 2,130 & 4 & 30 & .000 & 1,129 \\
\hline
\end{tabular}

Predictors: (Constant), Cash Flow to Equity Cash, Flow From Operating Activities ,

Operating Profit Margin, Investment Opportunity Set

b. Dependent Variable: Dividend Policy

Source: SPSS 20 Research Results

From the table above, it is known that the Durbin-Watson value obtained is 1.129 , which means the DW value is between -2 to +2 , so it can be concluded that there is no autocorrelation from Durbin Watson's figure.

Table 4.9 Multiple Linear Regression Results

Coefficientsa

\begin{tabular}{|c|c|c|c|c|c|}
\hline \multirow{2}{*}{ Model } & \multicolumn{2}{|c|}{$\begin{array}{c}\text { Unstandardized } \\
\text { Coefficients }\end{array}$} & \multirow{2}{*}{$\begin{array}{c}\begin{array}{c}\text { Standardized } \\
\text { Coefficients }\end{array} \\
\text { Beta }\end{array}$} & \multirow{2}{*}{$\mathbf{T}$} & \multirow{2}{*}{ Sig. } \\
\hline & B & $\begin{array}{l}\text { Std. } \\
\text { Error }\end{array}$ & & & \\
\hline (Constant) & 12.183 & .972 & & 8060 & .000 \\
\hline IOS & .730 & .567 & .527 & 4.927 & .000 \\
\hline OPM & .356 & .331 & .289 & 2,542 & .034 \\
\hline Cash Flow Form Operating Activities & .102 & .300 & .119 & 1.027 & .094 \\
\hline Cash Flow to Equity & .580 & .425 & .308 & 3.566 & .007 \\
\hline
\end{tabular}

a. Dependent Variable: Dividend Policy

Source: SPSS 20 Research Results

Based on table 4.5 above, the multiple linear regression equation is formulated as follows:

$$
\mathrm{Y}=12.183+0.730 \mathrm{X} 1+0.356 \mathrm{X} 2+0.356 \mathrm{X3}+0.102 \mathrm{X} 4+0.580
$$

The interpretation of the regression above is as follows:

1) The constant value (a) is 12,183 with a positive relationship direction indicating that if all the independent variables are Investment Opportunity Set, Operating Profit Margin, Cash Flow From Operating Activities, , Cash Flow tro Equity inside is zero, then Dividend Policy (DPR) on Metal Companies Listed on the Indonesia Stock Exchange for the 2016-2020 Periodstill worth 12,183 .

2) Value is Investment Opportunity Set(X1) of 0.730 . With a positive relationship direction, it shows that ifInvestment Opportunity Set improved 100\% then Dividend Policywill increase by 0.730 with the assumption that the other independent variables are constant. 
Influence Investment Opportunity Set, Operating Profit Margin, Cash Flow From Operating Activities And Cash Flow To Equity On Policy Dividend On A Metal Company That Listed On Indonesia Stock Exchange

DOI: $10.54443 /$ morfai.v1i2.102

3) Score Operating Profit Margin(X2) of 0.356. With a positive relationship direction, it shows that ifOperating Profit Margin improved 100\% then Dividend Policywill increase by 0.356 with the assumption that the other independent variables are constant.

4) Score Cash Flow From Operating Activities (X3) is 0.102. With a positive relationship direction indicates that ifCash Flow From Operating Activities improved 100\% then Dividend Policywill increase by 0.102 with the assumption that the other independent variables are constant.

5) Score Cash Flow to Equity (X4) is 0.580 . With a positive relationship direction, it shows that ifCash Flow to Equity improved $100 \%$ then Dividend Policywill increase by 0.580 with the assumption that the other independent variables are constant.

\subsection{Partial Test (t-test)}

The $t$ test is used to test the regression coefficients individually, this test is carried out to find out whether partially each independent variable has a significant effect or not on the dependent variable. After obtaining t count compared with t table.

Decision making criteria:

1) $\mathrm{H} 0$ is accepted if : $-t_{\text {table }} t$ count $t$ table

2) H0 is rejected if: $t_{\text {count }}>t_{\text {table }}$ or $-t_{\text {count }}<-t_{\text {table }}$

Table 4.10 T-Test Results (Partial)

Coefficientsa

\begin{tabular}{|c|c|c|c|c|c|}
\hline \multirow{2}{*}{ Model } & \multicolumn{2}{|c|}{$\begin{array}{c}\text { Unstandardized } \\
\text { Coefficients }\end{array}$} & \multirow{2}{*}{$\begin{array}{c}\text { Standardized } \\
\text { Coefficients } \\
\text { Beta }\end{array}$} & \multirow{2}{*}{$\mathbf{t}$} & \multirow{2}{*}{ Sig. } \\
\hline & B & $\begin{array}{l}\text { Std. } \\
\text { Error }\end{array}$ & & & \\
\hline (Constant) & 12.183 & .972 & & 8060 & .000 \\
\hline IOS & .730 & .567 & .527 & 4.927 & .000 \\
\hline 1 OPM & .356 & .331 & .289 & 2,542 & .034 \\
\hline Cash Flow Form Operating Activities & .102 & .300 & .119 & 1.027 & .094 \\
\hline Cash Flow to Equity & .580 & .425 & .308 & 3.566 & .007 \\
\hline
\end{tabular}

a. Dependent Variable: Dividend Policy

Source: SPSS 20 Research Results

\section{Effect of Investment Opportunity Set on Dividend Policy}

The $t$ test is used to determine whether Investment Opportunity Set individually (partially) have a significant relationship or not to Dividend Policy. From the SPSS 20 data processing, the ttest can be obtained as follows:

tcount $=4,927$

ttable $=2.034$

From the decision making criteria:

HO is accepted if : $-2,034 \leq \mathrm{t}_{\text {count }} 2.034$ at $=0.05$

HO is rejected if: $t_{\text {count }}>2,034$ or $-t_{\text {count }}<-2,034$ 


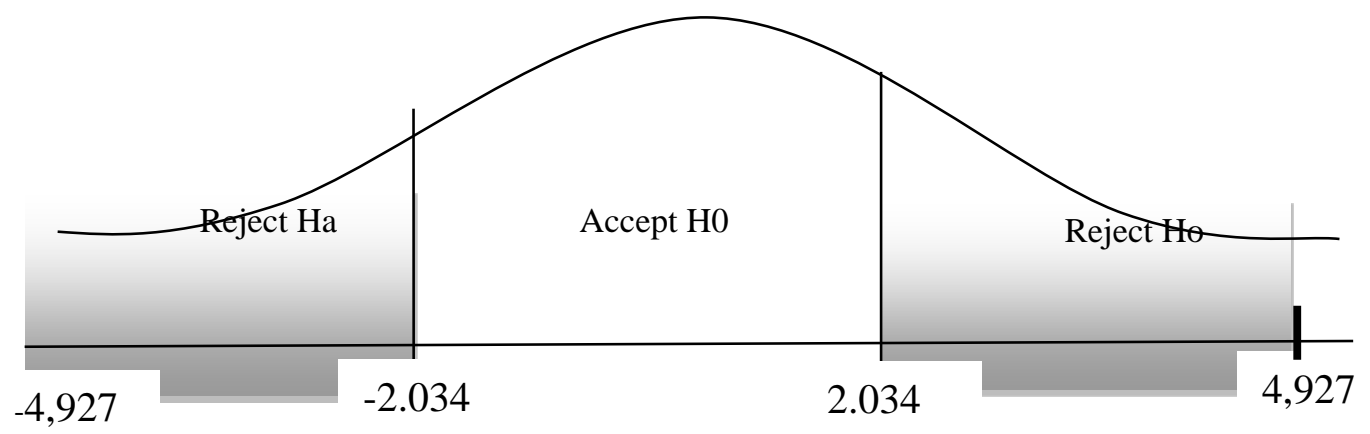

Figure 4.3 Criteria for Hypothesis Testing t . Test

Based on the partial test results, the effect of Investment Opportunity Set is 4.927 and ttable is 2.034. Thus, tcount is greater than ttable $(4.927>2.034)$ and has a significant number of $0.000<$ 0.05 . This means that $\mathrm{H} 0$ is rejected and $\mathrm{Ha}$ is accepted, this shows that partially there is an effect of Investment Opportunity Set on Dividend Policy.

\section{Effect of Operating Profit Margin on Dividend Policy}

$\mathrm{t}$ test used to find out whether the Operating Profit Margin individually (partial) has a significant relationship or not to Dividend Policy. From the SPSS 20 data processing, the t-test can be obtained as follows: tcount $=2,542$

ttable $=2.034$

From the decision making criteria:

$\mathrm{H} 0$ is accepted if : $-2,034 \leq \mathrm{t}_{\text {count }} 2.034$ at $=0.05$

$\mathrm{H} 0$ is rejected if: $\mathrm{t}_{\text {count }}>2,034$ or $-\mathrm{t}_{\text {count }}<-2,034$

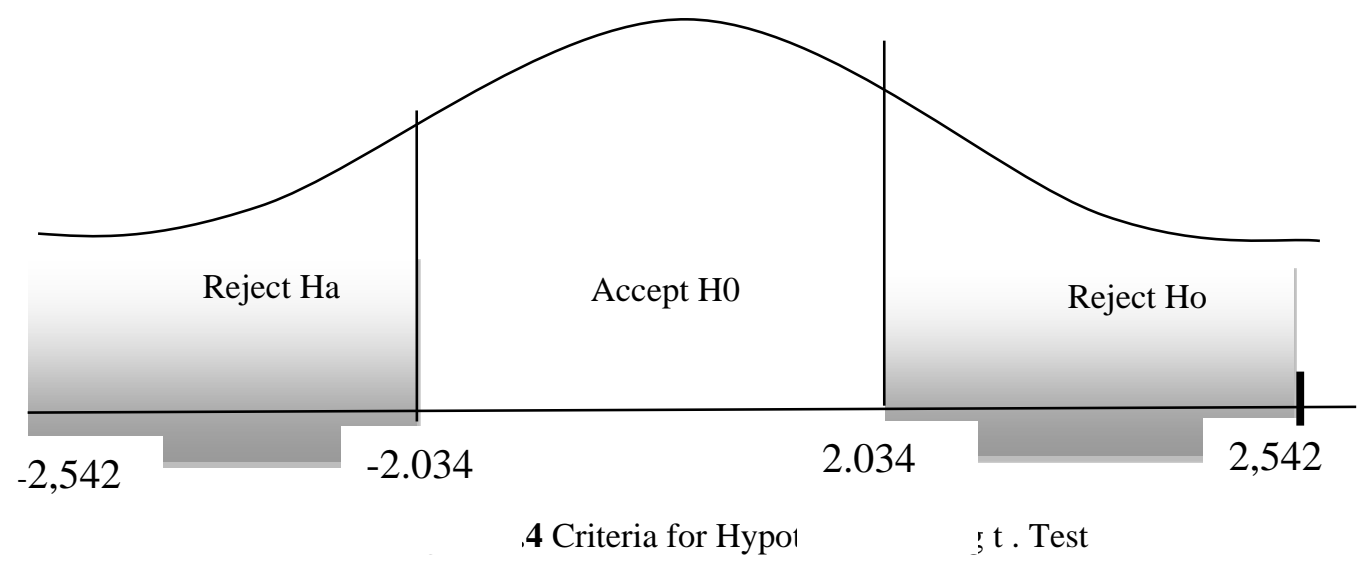

Based on the test results partially the effect of Operating Profit Margin2,542 and ttable of 2,034 . Thus, tcount is greater than ttable $(2.542>2.034)$ and has a significant number of $0.034<$ 0.05 . This means that $\mathrm{H} 0$ is rejected and $\mathrm{Ha}$ is accepted, this shows that partially there is an effectOperating Profit Marginto Dividend Policy. 
Influence Investment Opportunity Set, Operating Profit Margin, Cash Flow From Operating Activities And Cash Flow To Equity On Policy Dividend On A Metal Company That Listed On Indonesia Stock Exchange

DOI: $10.54443 /$ morfai.v1i2.102

\section{Effect of Cash Flow From Operating Activities on Dividend Policy}

The $t$ test is used to determine whether Cash Flow From Operating Activities individually (partially) have a significant relationship or not to Dividend Policy. From the SPSS 20 data processing, the t-test can be obtained as follows:

tcount $=1.027$

ttable $=2.034$

From the decision making criteria:

$\mathrm{H} 0$ is accepted if : $-2,034 \mathrm{t}_{\text {count }} 2.034$, at $=0.05$

HO is rejected if: $\mathrm{t}_{\text {count }}>2,034$ or $-\mathrm{t}_{\text {count }}<-2,034$

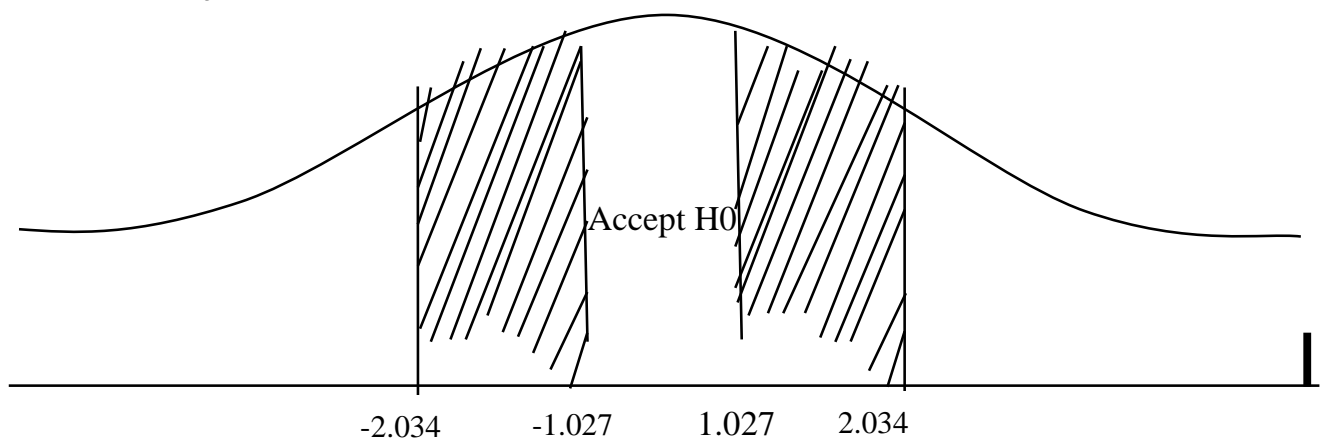

Figure 4.4 Criteria for Hypothesis Testing $\mathrm{t}$. Test

Based on the test results partially the effect of Cash Flow From Operating Activities 1.027 and ttable of 2.034. Thus, tcount is smaller than ttable $(-2.034<1.027<2.034)$ and has a significant number of $0.094>0.05$. This means that $\mathrm{H} 0$ is accepted and $\mathrm{Ha}$ is rejected, this shows that partially there is no effect of Cash Flow From Operating Activities on Dividend Policy.

\section{InfluenceCash Flow to Equity to Dividend Policy}

$\mathrm{t}$ test used to find out whether Cash Flow to Equity individually (partial) has a significant relationship or not to Dividend Policy. From the SPSS 20 data processing, the t-test can be obtained as follows:

tcount $=3,566$
ttable $=2.034$

From the decision making criteria:

H0 is accepted if : $-2,034 \leq t_{\text {count }} 2.034$ at $=0.05$

$\mathrm{H} 0$ is rejected if: $\mathrm{t}_{\text {count }}>2,034$ or $-\mathrm{t}_{\text {count }}<-2,034$

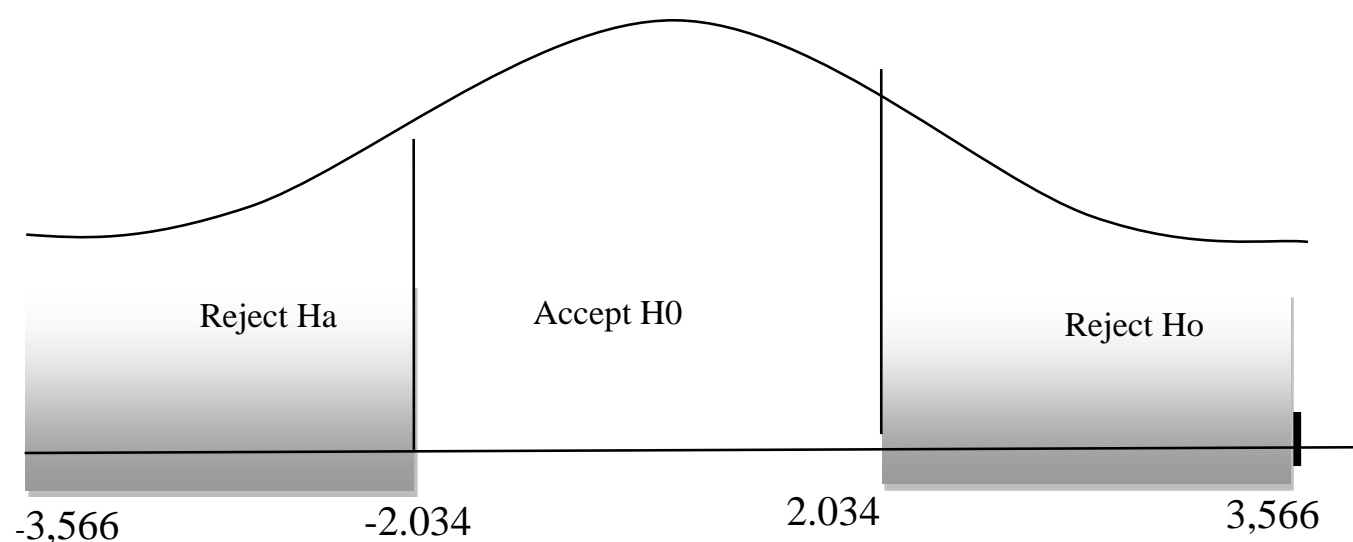

Figure 4.5 Criteria for Hypothesis Testing t. Test 


\section{ORFAI JOURNAL

Based on the partial test results Cash Flow to Equity3,566 and ttable of 2,034. Thus, tcount is greater than ttable (3.566> 2.034) and has a significant number of $0.007<0.05$. This means that $\mathrm{H} 0$ is rejected and $\mathrm{Ha}$ is accepted, this shows that partially there is an effectCash Flow to Equityto Dividend Policy.

\section{Simultaneous F Test}

The $\mathrm{F}$ test is also called the significant test which is jointly included to see the overall ability of the independent variables, namely the Investment Opportunity Set, Operating Profit Margin, Cash Flow From Operating Activities, Cash Flow to Equity, Cash Flow to Equityin influencing Dividend Policy.

\section{Test criteria:}

Reject $\mathrm{H}_{0}$ if Fcount $>$ Ftable or -Fcount $<$-Ftable

Thank $\mathrm{H}_{0}$ if Fcount $<$ Ftable or -Fcount $>$-Ftable

Based on the results of data processing with the SPSS version 20 program, the following results were obtained:

Table 4.7 F-Test Results (Simultaneous)

ANOVAa

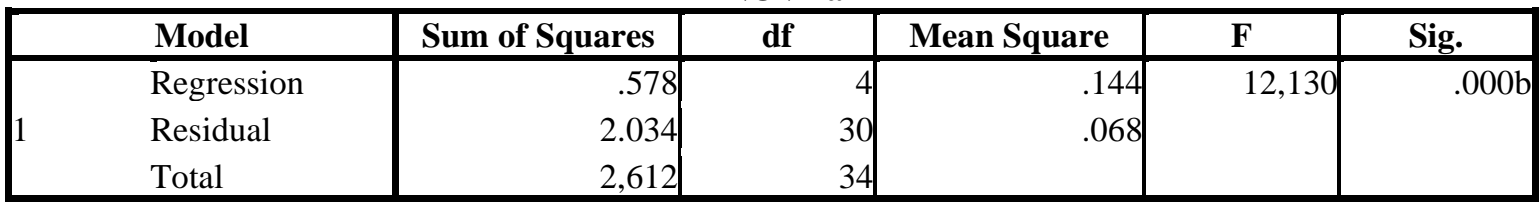

a. Dependent Variable: Dividend Policy

b. Predictors: (Constant), Cash Flow to Equity, IOS, Cash Flow form Operating Activities, OPM

Source: SPSS 20 Research Results

Aims to test the statistical hypothesis above, then the $\mathrm{F}$ test is carried out at level $=5 \%$. The calculated $\mathrm{F}$ value for $\mathrm{n}=35$ is as follows:

Fcount $=12,130$

Ftable $=$ nk-1 $=35-3-1=31$

The value of Ftable for $n=31$ is 2.68. Furthermore, the value of Ftable of 2.68 is used as a decision-making criterion.

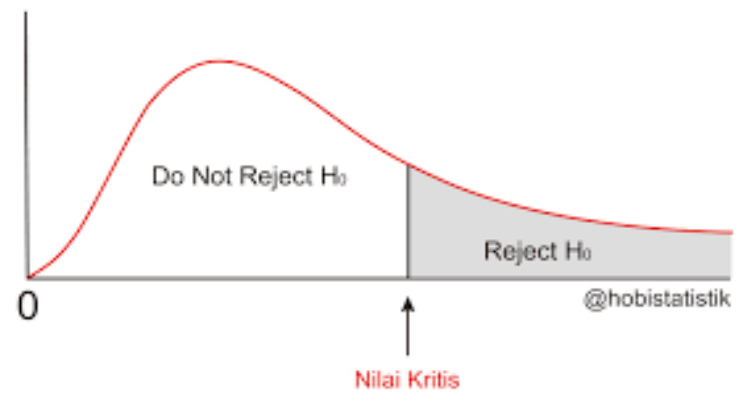

Figure 4.5 F Test Hypothesis Testing Criteria

Based on the results of simultaneous testing using Fcount and Ftable tests. The effect of Investment Opportunity Set, Operating Profit Margin, Cash Flow From Operating Activities, Cash Flow to Equity on Dividend Policy obtained Fcount of 12,130 with Ftable of 2.68 so that Fcount is greater than Ftable $(12,130>2,68)$ and has a significant number of $0.00<0.05$. This means that $\mathrm{H} 0$ is rejected and $\mathrm{Ha}$ is accepted, this shows that there is an effect of the Investment Opportunity Set, Operating Profit Margin, Cash Flow From Operating Activities, Cash Flow to Equity together on the Dividend Policy, in other words the Investment Opportunity Set, Operating Profit Margin, Cash Flow 
Influence Investment Opportunity Set, Operating Profit Margin, Cash Flow From Operating Activities And Cash Flow To Equity On Policy Dividend On A Metal Company That Listed On Indonesia Stock Exchange

DOI: $10.54443 /$ morfai.v1i2.102

From Operating Activities, Cash Flow to Equity simultaneously affect the level of Dividend Policy directly.

\section{Coefficient of Determination}

The coefficient of determination $\left(\mathrm{R}^{2}\right)$ serves to see the extent to which the overall independent variable can explain the dependent variable. If the coefficient of determination is getting stronger, it means that the independent variables provide almost all the information needed to predict the variation of the dependent variable. While the small value of the coefficient of determination (adjusted R2) means that the ability of the independent variables to explain the dependent variation is limited. Here are the statistical test results.

Table 4.8 Coefficient of Determination Test

Model Summaryb

\begin{tabular}{|c|c|c|c|c|c|c|c|c|c|c|}
\hline \multirow[b]{2}{*}{ Model } & \multirow[b]{2}{*}{$\mathbf{R}$} & \multirow{2}{*}{$\begin{array}{c}\mathbf{R} \\
\text { Square }\end{array}$} & \multirow{2}{*}{$\begin{array}{l}\text { Adjusted } \\
\text { R Square }\end{array}$} & \multirow{2}{*}{$\begin{array}{l}\text { Std. Error } \\
\text { of the } \\
\text { Estimate }\end{array}$} & \multicolumn{5}{|c|}{ Change Statistics } & \multirow[b]{2}{*}{ Durbin Watson } \\
\hline & & & & & \begin{tabular}{|c|} 
R Square \\
Change
\end{tabular} & F Change & df1 & df2 & $\begin{array}{l}\text { Sig. F } \\
\text { Change }\end{array}$ & \\
\hline 1 & $.470 \mathrm{a}$ & .221 & .117 & .26041 & .221 & 2,130 & )] & 30 & .000 & 1,129 \\
\hline
\end{tabular}

a. Predictors: (Constant), Cash Flow to Equity, IOS, Cash Flow form Operating Activities, OPM

b. Dependent Variable: Dividend Policy

Source: SPSS 20 Research Results

Based on the results of the coefficient of determination in the table above, it shows the value of R Square is 0.221. To find out the extent of the influence of the Investment Opportunity Set, Operating Profit Margin, Cash Flow From Operating Activities, Cash Flow to Equity Ratio variables together on Dividend Policy, it can be known through the coefficient of determination test as follows:

$$
\begin{aligned}
\mathrm{KD} & =\mathrm{R} 2 \times 100 \% \\
& =0,4702 \times 100 \% \\
& =22.1 \%
\end{aligned}
$$

R-value Square above is $22.1 \%$ this means that $22.1 \%$ of the variation in the value of the Dividend Policy is determined by the role of variations in the value of the Investment Opportunity Set, Operating Profit Margin, Cash Flow From Operating Activities, Cash Flow to Equity. In other words, Investment Opportunity Set, Operating Profit Margin, Cash Flow From Operating Activities, Cash Flow to Equity in influencing Dividend Policy are 22.1\% while the remaining $77.9 \%$ is influenced by other variables not included in this study such as structure assets and sales growth.

\section{DISCUSSION}

\section{Effect of Investment Opportunity Set on Dividend Policy}

Based on the results of research obtained regarding the Investment Opportunity Set on Dividend Policy in Metal Companies Listed on the Indonesia Stock Exchange for the 2016-2020 period, it is stated that tcount is greater than ttable $(4.927>2.034)$ and has a significant number of $0.000>0.05$. This means that $\mathrm{H} 0$ is rejected and $\mathrm{Ha}$ is accepted. The results of this hypothesis test indicate that partially there is a significant effect of Investment Opportunity Set on Dividend Policy in Metal Companies Listed on the Indonesia Stock Exchange for the 2016-2020 Period. Investment Opportunity Set (IOS) is an investment opportunity for a company to improve the company. Companies that have investment opportunities will prefer internal funding over external, because internal funding is cheaper(Jensen, 2011). 


\section{Effect of Operating Profit Margin on Dividend Policy}

Based on the results of research obtained regarding the Operating Profit Margin on Dividend Policy in Metal Companies Listed on the Indonesia Stock Exchange for the 2016-2020 period, it is stated that tcount is smaller than ttable $(2.542>2.034)$ and has a significant number of $0.034<0.05$. This means that $\mathrm{HO}$ is rejected and $\mathrm{Ha}$ is accepted. The results of this hypothesis test show that partially there is an effect of Operating Profit Margin on Dividend Policy in Metal Companies Listed on the Indonesia Stock Exchange for the 2016-2020 period.

According to (Harmono, 2015)Operating Profit Marginis the ratio between operating profit and sales. OPM shows the company's ability to generate profits with sales owned. And then analyzed to project the company's ability to generate profits in the future. The higher the profit received by the company, the higher the availability of funds allocated to the company for dividends will be. This will affect the size of the company's DPR.

\section{Effect of Cash Flow From Operating Activities on Dividend Policy}

Based on the results of research obtained regarding Cash Flow From Operating Activities on Dividend Policy in Metal Companies Listed on the Indonesia Stock Exchange for the 2016-2020 period, it is stated that tcount is smaller than ttable $(-2,034<1.027<2.034)$ and has a significant number of $0.094>0,05$. This means that $\mathrm{HO}$ is accepted and $\mathrm{Ha}$ is rejected. The results of this hypothesis test show that partially there is no significant effect of Cash Flow From Operating Activities on Dividend Policy in Metal Companies Listed on the Indonesia Stock Exchange for the 2016-2020 Period.

CashFlow form Operating Activitiesis excess cash in the company that can be distributed to shareholders in the form of dividends (Brigham and Houston, 2016). The distribution can be done after the company makes capital expenditures such as purchasing fixed assets in cash.(Jensen, 2011)states that Operating Profit Margin has a positive effect on dividend payoutratio. The higher the CashFlow form Operating Activities, the higher the dividend payout ratio or vice versa.(Jensen, 2011) linking the Operating Profit Margin with agency theory.

\section{Effect of Cash Flow to Equity on Dividend Policy}

Based on the results of research obtained regarding Cash Flow to Equity on Dividend Policy in Metal Companies Listed on the Indonesia Stock Exchange for the 2016-2020 period, it is stated that tcount is greater than ttable (3.566>2.034) and has a significant number of $0.007>0.05$. This means that $\mathrm{HO}$ is rejected and $\mathrm{Ha}$ is accepted. The results of this hypothesis test show that partially $\mathrm{t}$ has a significant effect on Cash Flow to Equity on Dividend Policy in Metal Companies Listed on the Indonesia Stock Exchange for the 2016-2020 Period.

Research result (Lucyanda, 2015) and (Saputro, 2017) states that Cash Flow to Equity has an effect on the Dividend Payout Ratio.

\section{Effect of Investment Opportunity Set, Operating Profit Margin, Cash Flow From Operating Activities, Cash Flow to Equity on Dividend Policy}

The results obtained regarding the effect of Investment Opportunity Set, Operating Profit Margin, Cash Flow From Operating Activities Cash Flow to Equity on Dividend Policy in Metal Companies Listed on the Indonesia Stock Exchange for the 2016-2020 Period from the ANOVA (Analysis Of Variance) test. In the table above, Fcount is 12.130 with a significant level of 0.000 , while Ftable is known to be 2.68. Based on these results, it can be seen that Fcount > Ftable (12.130 $>2.68$ ) so that $\mathrm{H} 0$ is rejected and $\mathrm{Ha}$ is accepted so it can be concluded that the variables of Investment Opportunity Set, Operating Profit Margin.

\section{CONCLUSION}

1. There is an Investment Opportunity Set that affects the Dividend Policy of Metal Companies Listed on the Indonesia Stock Exchange for the 2016-2020 Period. It showsthere is an additional 
Influence Investment Opportunity Set, Operating Profit Margin, Cash Flow From Operating Activities And Cash Flow To Equity On Policy Dividend On A Metal Company That Listed On Indonesia Stock Exchange

DOI: $10.54443 /$ morfai.v1i2.102

flow of the company's share capital for productive assets so that it has the potential to be an indicator of the company's growth. The greater the flow of additional share capital, the greater the company's ability to use it as an additional investment so that the company has the opportunity to grow which will increase dividends for the company.

2. There is influenceOperating Profit Margin on the Dividend Policy on Metal companies listed on the Indonesia Stock Exchange (IDX) for the period 2016 to. The results of this hypothesis test indicate that an increase in Operating Profit Margin means an increase in Dividend Policy, this shows The increase in company sales is followed by a decrease in the existing cost structure of the company, so that with the increase in the company's ability to generate profits it will cover fixed costs or other operating costs.

3. There is no influence of Cash Flow From Operating Activities on Dividend Policy in Metal companies listed on the Indonesia Stock Exchange (IDX) for the period 2016 to 2020. This shows The greater the amount of cash in the company, the higher the liquidity. This means that the company has a smaller risk of not being able to meet its financial obligations, but this does not mean that the company should try to maintain a very large cash supply, because the greater the cash means the more money that is unemployed so that it will reduce profits. On the other hand, if the company only pursues profit, the cash inventory can be turned over or in working condition. If the company carries out this action, it means placing the company in a liquid state if at any time there is a billing.

4. There is an effect of Cash Flow to Equity on Dividend Policy in Metal companies listed on the Indonesia Stock Exchange (IDX) for the period 2016 to 2020. The results of this hypothesis test indicate that the increase in Cash Flow to Equity is followed by an increase in the dividend payout ratio.So that when the company has sufficient cash flow to the company's equity, the company will able to make repayments to the owner of the funds (investors) and creditors.

5. Investment Opportunity Set, Operating Profit Margin, Cash Flow From Operating Activities, Cash Flow to EquitySimultaneously has a significant influence on the Dividend Policy of Metal Companies Listed on the Indonesia Stock Exchange for the 2016-2020 Period. This shows with increased investment, as well as increased sales and henceall cash transactions with shareholders and loan transactions and repayments with lenders.

\section{REFERENCES}

Agung, J. S. (2015). Konsep dan Pengukuran Investment Opportunity Set pengaruhnya pada proses kontrak". Jurnal Akuntansi dan Manajemen. Jurnal Akuntansi dan Manajemen, 16(2), 141152.

Anugrah, A. D. P. (2014). Analisis Pengaruh Investment Opportunity Set (IOS) Terhadap Return Saham Perusahaan Sektor Manufaktur. Journal of Business and Management, 7(2), 94-100.

Brigham, \& Houston. (2016). Dasar-Dasar Manajemen Keuangan (Edisi 11.). Jakarta: Salemba Empat.

Daud, R. M. (2017). Pengaruh Operating Profit Margin, Dividend Payout Ratio, Profitabilitas, Dan Price Earning Ratio Terhadap Praktik Perataan Laba Pada Perusahaan LQ-45 Yang Terdaftar Di Bursa Efek Indonesia Tahun 2010-2014. Jurnal Akuntansi Muhammadiyah-JAM, 8(1), 110.

Djarwanto. (2014). Pokok-pokokAnalisis Laporan Keuangan. Yogyakarta: BPFE.

Fahmi, I. (2014). Analisa Kinerja Keuangan. Bandung: Alfabeta.

Gudono, M. (2017). Hubungan Tindakan Perataan Laba dengan Reaksi Pasar atas Pengumuman Informasi Laba Perusahaan yang Terdaftar Di Bursa Efek Jakarta. Jurnal Ventura, 10(2), 114.

Gumanti, T. A. (2013). Kebijakan Deviden Teori,Empiris, dan Implikasi. Jakarta: UPP STIM YKPN.

Gumantri, T. A. (2013). Kebijakan Dividen Teori, Empiris, dan Implikasi. Jakarta: UPP STIM YKPN. 
Halim, A. (2014). Manajemen Keuangan Sektor Publik,Problematika Penerimaan Dan Pengeluaran Pemerintah (Anggaran Pendapatan dan Belanja Negara/Daerah). Jakarta: Salemba Empat.

Harahap, S. S. (2013). Analisis Kritis Atas Laporan Keuangan. Jakarta: Rajawali Pers.

Harjito, A., \& Martono. (2013). Manajemen Keuangan (2nd ed.). Yogyakarta: Ekonisia.

Harmono. (2015). Manajemen Keuangan Bebasis Balenced Scorecard Pendekatan Teori, Kasus, dan Riset Bisnis. Jakarta: Bumi Angkasa.

Harnanto. (2013). Akuntansi Keuangan Menengah, Edisi 2003/2004,. Yogyakarta: BPFE.

Hartono. (2011). Teori Portofolio dan Analisis Investasi. Edisi. Kesepuluh. Yogyakarta: Andi.

Hasnawati, S. (2015). Dampak Set Peluang Investasi Terhadap Nilai Perusahaan Publik di Bursa Efek Jakart. JAAI, 9(2), 117-126.

Horne, J. C. Van, \& Wachowicz, J. M. (2012). Prinsip-prinsip Manajemen Keuangan (13th ed.). Jakarta: Salemba Empat.

IAI. (2009). Pernyataan Standar Keuangan 01: Penyajian. Laporan Keuangan (Revisi 2009). Jakarta: IAI.

Jensen, M. C. (2011). Theory of the firm: Managerial behavior, agency cost and ownership structure. Journal of Finance Economic, 3(1), 305-360.

Juliandi, A., Irfan, I., \& Manurung, S. (2015). Metode Penelitian Bisnis. Medan: UMSU Press.

Kadir, A., \& Phang, S. (2012). Analisis Faktor-Faktor yang Mempengaruhi Net Profit Margin Perusahaan Manufaktur yang Terdaftar pada Bursa Efek Indonesia, 13(1), 1-16.

Kallapur, S. dan T. (2016). The Invesment Opportunity Set: Determinant, Consequences and Measurement. Manajerial Finance (pp. 3-15).

Lucyanda, J. (2015). Pengaruh Free Cash Flow Dan Struktur Kempemilikan Terhadap Dividend Payout Ratio. Jurnal Dinamika Akuntansi, 4(2), 129-138.

Midiastuty. (2013). Analisis Hubungan Mekanisme Corporate Governance dan Indikasi Manajemen Laba. Artikel Simposium Nasional Akuntansi (SNA) VI, Surabaya (pp. 27-32).

Munawir, S. (2014). Analisis Laporan Keuangan. Yogyakarta: Liberty.

Murhadi, W. R. (2013). Analisis Laporan Keuangan Proyeksi dan Valuasi saham. Jakarta: Salemba Empat.

Norpratiwi, M. V. (2017). Analisis Korelasi Investment Opportunity Set terhadap Return Saham (Pada Saat Pelaporan Keuangan Perusahaan). Jurnal Keuangan dan Perbankan., 9(3), 369383.

Prastowo. (2014). Analisis Laporan Keuangan, Edisi Kedua. Yogyakarta: UUP AMP YKPN.

Purnami, K. D. A. (2016). Pengaruh Investment Opportunity Set, Total Asset Turn Over Dan Sales Growth Terhadap Kebijakan Dividen. E-Jurnal Manajemen Unud, 5(2), 1309-1337.

Puspitasari, N. L. P. (2016). Pengaruh Investment Opportunity Set (IOS) pada Kebijakan Dividen Tunai Dengan Umur Perusahaan Sebagai Variabel Pemoderasi. E-Jurnal Ekonomi dan Bisnis Universitas Udayana, 5(5), 1335-1358.

Reeve, M. (2014). Pengantar Akuntansi Adaptasi-Indonesia. Jakarta: Salemba Empat.

Riyanto, B. (2015). Dasar-Dasar Pembelanjaan Perusahaan. Yogyakarta: BPFE.

Ross, A. (2016). Pengantar Kuangan Perusahaan. Jakarta: Salemba Empat.

Rudianto. (2015). Pengantar Akuntansi Konsep \& Teknik Penyusunan Laporan Keuangan. Jakarta: Penerbit Erlangga.

Saputro, W. H. A. (2017). Pengaruh Profitabilitas, Free Cash Flow, Investment Opportunity Set Dan Leverage Terhadap Divident Payout Ratio. Widi Hastomo Adi Saputro (pp. 90-98).

Saragih, F. (2012). Pengaruh Laba Bersih Dan Arus Kas Operasi Terhadap Dividen Kas Pada Perusahaan Manufaktur Yang Terdaftar Di Bursa Efek Indonesia. Ekonomikawan: Jurnal Ekonomi \& Studi Pembangunan, 10(1-18).

Sari, R. F. (2018). Analisis Pengaruh Kepemilikan Manajerial, Kebijakan Utang, Profitabilitas, Ukuran Perusahaan, dan Kesempatan Investasi terhadap Kebijakan Dividen. Jurnal riset akuntansi Indonesia, 4(1), 1-13. 
Influence Investment Opportunity Set, Operating Profit Margin, Cash Flow From Operating Activities And Cash Flow To Equity On Policy Dividend On A Metal Company That Listed On Indonesia Stock Exchange

DOI: $10.54443 /$ morfai.v1i2.102

Sawir, A. (2018). Analisis Kinerja Keuangan dan Perencanaan Keuangan Perusahaan. Jakarta: PT. Gramedia Pustaka Utama.

Sudana, I. M. (2015). Manajemen Keuangan Perusahaan. Edisi Kedua. Jakarta: Erlangga.

Sugiyono. (2015). Metode Penelitian Kuantitatif Kualitatif Dan R\& D. Bandung: Alfabeta.

Sugiyono. (2016). Metode Penelitian Kuantitatif, Kualitatif, dan R\&D. Bandung: Alfabeta.

Sumarni, I. (2014). Pengaruh Investment Opportunity Set Terhadap Kebijakan Dividen. Jurnal Wawasan Manajemen, 2(2), 201-211.

Sunarto, \& Budi, A. P. (2010). Pengaruh Leverage, Ukuran Perusahaan dan Pertumbuhan Perrusahaan terhadap Profitabilitas. Telaah Manajemen Marlie, 6(1), 86-103.

Suryabrata, S. (2015). Metodologi Penelitian. Jakarta: Raja Grafindo Persada.

Syakur, A. S. (2015). Intermediate Accounting. Jakarta: AV Publisher.

Topowijono. (2016). Pengaruh Profitabilitas dan Leverage Terhadap Harga Saham (Studi pada Perusahaan Konstruksi dan Bangunan yang Terdaftar di Bursa Efek Indonesia Periode 20112014). Jurnal Administrasi Bisnis, 35(2), 181-188.

Warren, C. S. (2015). Pengantar Akuntansi. Jakarta: Salemba Empat.

Wirawati, A. K. (2016). Pengaruh inflasi, nilai tukar rupiah, suku bunga SBI pada indeks harga saham gabungan di BEI. E-Jurnal Akuntansi, 3(2), 421-435.

Yahya, D. K. (2017). Menumbuhkan dan Mempertahankan Kesetiaan Pelanggan. Jakarta: Husein Umar. 